\title{
VERDADE E FICÇÃO EM TEXTOS UTÓPICOS
}

\author{
Bento Itamar Borges \\ U niversidade Federal de U berlândia \\ bentoib@ufu.br
}

\begin{abstract}
RESU MO: Considerados do ponto de vista da teoria literária, os textos filosóficos que tratam explicitamente da política caem sobretudo sob os gêneros do tratado e do ensaio, mas, indiretamente, a teoria política sofre a influência das utopias, literárias ou experimentadas de fato. A validade de um tratado - e certamente também da enviesada crítica da economia política - depende do método que o sustenta, ao passo que no ensaio pesam as credenciais daquele que emite uma opinião. Por fim, cabe questionar o que significa o requisito da verdade nos textos utópicos, que variam da nostal gia ao sonho: 0 passado seria objeto da cronologia, que averiguaria a ocorrência de ilhas e paraísos, mas é muito difícil avaliar enunciados contrafatuais e sobre eventos futuros. A literatura sabe lidar com a ficção, enquanto a filosofia quer salvar pelo menos a crítica da pólis em seu momento presente.
\end{abstract}

Palavras-chave: ficção, verdade, filosofia.

A poesia submete ao nosso exame jardins imaginários com sapos autênticos.

(M arianne M oore, apud W ellek eWarren)

\section{D efesa do tema: utopia}

Podemos ainda falar seriamente de utopia, depois que 0 socialismo científico apontou as fraquezas do socialismo utópico? Q ueremos nos contentar com a solução moderada da engenharia social? A contradição ainda operante entre progresso e crise parece reclamar a fantasia em momentos que deixam conviver a mistificação da técnica, enquanto fé no progresso, e a incapacidade da crítica, que não consegue retirar da crise mesma a imagem de sua superação. 
0 jovem Horkheimer, ao defender uma transformação do todo social, mediante a teoria crítica, quis distingui-la da utopia "pela prova de sua possibilidade real fundada nas forças produtivas humanas desenvolvidas", ${ }^{1}$ ao mesmo tempo em queresgatou o papel da fantasia a guiar os esforços históricos: "este pensamento tem algo em comum com a fantasia". A categoria "utopia" tem nesse texto-programa da teoria crítica um sentido definitivamente negativo, pois "o teórico que se encontra em oposição [à classe dominante] é considerado às vezes como inimigo e criminoso, às vezes como utopista e alienado do mundo", ao passo que a fantasia éa imagem da tenacidade que as vanguardas deveriam introduzir nas camadas dominadas.

Martin Buber encarregou-se de recuperar o significado do socialismo utópico, em um estudo que deveria passar acima das intrigas internas do movimento operário na segunda metade do século XIX. Inicialmente, como no $M$ anifesto, $M$ arx e Engels davam o nome de utopistas "àqueles cujas idéias precederam o desenvolvimento decisivo da indústria, do proletariado e da luta de classes, e os quais não poderiam, por isso, levar estes fatores em consideração", porém, maistarde, o rótulo passa a ter um efeito retórico, no campo semântico que polariza o científico e a verdade, de um lado, e 0 utópico e equivocado, do outro. 0 rótulo funda-se em um argumento circular: "ser 'utopista' significa não estar à altura do moderno desenvolvimento industrial; o que seja moderno desenvolvimento industrial ensina-nos o marxismo". ${ }^{3}$

U tópico, na polêmica de Marx e Engels, é o socialismo voluntarista, que apela à razão, à justiça e à vontade do homem, em vez de limitar-se a apresentar à consciência ativa o que as condições de produção já haviam preparado dialeticamente. Buber questiona, todavia, se o dito socialismo científico, que se quer superior, estaria de fato isento de elementos utópicos.

Buber quer, sem qualquer romantismo e sem fugir do presente, associar autonomia e comunitarismo: "O socialismo 'utópico' luta pelo máximo de autonomia comunitária possível, dentro de 
uma reestruturação da sociedade."4 Todavia, não se deve supor que ele queira restabelecer um modelo arcádico de comunismo agrário primitivo ou de um estado corporativo cristão medieval. Pior que ser rotulado de utopista é ser associado a uma utopia, com conteúdo específico, sobretudo de inspiração religiosa.

Em 1984, ao discursar diante do parlamento espanhol, $\mathrm{H}$ abermas tematizou a perda de confiança em si mesma da razão ocidental, como um certo esgotamento das energias utópicas. Parece, de início, que o pensamento histórico e o pensamento utópico se excluem. "O pensamento histórico, saturado de experiência, parece chamado a criticar os projetos utópicos; e o tran sbordante pensamento utópico parece ter a função de iluminar espaços de possibilidade que apontam mais além das continuidades históricas, nas quais irrompe." O discurso de H abermas não é apenas uma comemoração da posse de um primeiro-ministro socialista; mais que isso, H abermas marcava posição contra a onda que, por trás de um pessimismo cultural transitório, queria decretar a vigência de uma época pósmoderna. 0 que o filósofo alemão defendia como "projeto inacabado do racionalismo" poderia, por sua vez, ser ainda rotulado de grande discurso utópico da modernidade, mas seria um equívoco associarem-se apressadamente razão e utopia, para postular-se um esvaziamento da primeira. 0 que tem desaparecido, segundo $\mathrm{H}$ abermas - que àquela época montava 0 quadro categorial para sua teoria do agir comunicativo -, são conteúdos utópicos da sociedade do trabal ho. A gora, chama-se a aten ção para novas formas de vida que demonstram desenvolvimentos de uma nova confluência deenergias utópicas e históricas em direção à interação. ${ }^{5}$

\section{D efesa da abordagem: literatura e filosofia}

A ristóteles disse que a poesia (isto é, a épica e o drama) está mais perto da filosofia do que da história. Esta asserção parece conservar o poder sugestivo. Existe a verdade dos fatos, a verdade 
nos específicospormenores de tempo elugar - a verdade da história em sentido estrito. Temos, depois, a verdade filosófica: conceptual, propositiva, geral. Encarada desses pontos de vista (da "história", assim entendida, e da filosofia), a literatura de imaginação é uma "ficção", uma mentira, e não se pode, portanto, tomar o romance a sério, como se se tratasse de um documento ou de uma ficha clínica - essa recepção étão perigosa quanto considerar que a poesia fosse mais instrutiva e o romance, mero entretenimento. ${ }^{6}$ Embora o romance tenha se formado também sob a influência dos relatos de viagem e de princípios do realismo literário, "os horrendos castelos de Poe não se situam na Alemanha ou na Virgínia, mas sim na alma". 7

Temos de distinguir o gênero literário "utopia" da ideologia, que é o "utopismo", seja em Buber, Tillich e mesmo em Marx, apesar do padrão cientificista que ele visava. 0 utopismo engloba o gênero, mas compromete-se também com atitudes mentais e ideológicas. ${ }^{8}$ Seria necessário excluir também, de início, as "escatologias milenaristas", pois a verdadeira utopia tende a ser ela mesma uma religião; mais precisamente, conforme G. D ubois, "um ato de auto-adoração da cidade por si mesma". ${ }^{9}$ A través da figura da reurbanização, comum a muitos textos utópicos, ${ }^{10}$ deve-se deixar de fora também os experimentos de vida em comunidades, como na Inglaterra, entre 1900 e $1945 .^{11}$

Podemos hoje criticar como inviáveis alguns projetos apenas esboçados e os experimentos falidos após certa vigência, mas, em ambos os casos, é possível admitir algum sucesso em objetivos localizados. Experimentos de grupos que se refugiaram no campo ou no sertão, inclusive em oposição a um regime político central, como $\mathrm{C}$ anudos, têm interesse histórico, mas não literário. ${ }^{12}$

A delimitação do material, antes mesmo de uma caracterização, visa proteger nosso tema, pois "a descrição da utopia como gênero permite escapar a seu confisco pelas ideologias. Pouco importa aqui que ela seja antecipadora ou passadista, liberadora ou alienante, progressista ou reacionária". ${ }^{13}$ Todavia, lembram Wellek 
e Warren, o dilema que acomete a história dos gêneros é comum a toda história, pois, para descobrir o esquema de referências - no caso, o gênero - , temos de estudar a história, mas não a podemos estudar sem ter já uma idéia de um certo esquema de seleção. A ntes, porém, de apresentar alguns traços característicos e distintivos, é necessário lembrar que os autores de narrativas utópicas têm também intenções estéticas, pois, conforme Todorov, "uma obra literária não é apenas a resultante de um conjunto de princípios, 0 produto de uma combinatória preexistente, mas sim - e sobretudo, na medida em que ela quer ser original - uma transformação dessa combinatória". ${ }^{14}$

0 estudo dos gêneros literários en contra nos textos utópicos, em particular, um caso exemplar de "monogênese", ou seja, a partir de uma obra se constitui oficialmente um gênero ese definem obras anteriores. É por referênciaà obra de M orusque podemos classificar como utópicos os escritos dePlatão. Assim, entendendo-se um gênero literário como "um sistema de obras que, pela adição de obras novas, vê suas relações internas se modificar sem cessar, que aumenta como uma totalidade em movimento", torna-se possível fazer a história desse gênero a partir da definição autorizada pela descrição da obramãe. ${ }^{15}$

Trousson sustenta que o gênero "utopia" requer sobretudo a forma romance, ${ }^{16}$ a forma literária mais adequada para representar um universo construído a partir de um universo real e modificado pela especulação abstrata, pois a narrativa romanesca seria a "única suscetível de realizar a representação de um mundo em marcha, tão complexo quanto o mundo real, e dotado de uma vida plausível". ${ }^{17}$

C reio que seria mais adequado nos referirmos à narrativa - e não só ao romance -, pois há histórias curtas, mais próximas do conto, e em muitos textos, inclusive o de Morus, combinam-se também preâmbulos dialogados e outros recursos estilizados e ritualizados. 


\section{Características gerais do gênero utopia ${ }^{18}$}

a) Insularismo: cosmos miniaturizado, a ilha é a imagem ingênua da mentalidade que busca autonomia e da necessidade de preservar a comunidade, manten do-a longe da corrupção exterior, seja ela a anarquia pressentida no século XVI ou o totalitarismo do século XX.

b) Sistema agrícola e horror ao comércio: os utópicos desconfiam do ouro e da prata e até ridicularizam tais metais, ${ }^{19}$ pois odeiam a moeda em geral, causa de desigualdadese injustiças, "que rompem a uniformidadee a simetria das condições que a cidade ideal reclama". D aí a fobia pelo comércio e o culto a um sistema agrícola e de economia fechada.

c) Regularidade: 0 universo utópico deve funcionar como um relógio, as cidades são geometricamente traçadas, "signo visível do controle perfeito e total". A ilha de M orus tem 54 cidades iguais; a Cidade do Sol está organizada em sete círculos concêntricos; na I cária, de C abet, cada rua tem seis casas do mesmo estilo. M ais que a vontade do controle panóptico, devemos ver aí o amor pela ordem que setraduz no misticismo do número, que já em Platão manifesta a onipresença da regra justa.

d) Presentidade: 0 visitante típico da U topia, que depoisserá nosso narrador e guia, sempre chega lá no momento em que a cidade já está pronta, "em perfeita ordem de marcha". O s habitantes da U topia vivem em um presente definitivo e estático, na medida em que ela é fixista, sem passado e sem progresso, pois sen do perfeita já está pronta.

e) Legislação centralizada e outorgada por um sábio, como 0 bom rei U topus, de Morus, Hoh, o M etafísico, de Campanella, o grande Salomão da narrativa de Bacon e, 
também, na antiutopia de 0 rwell, o vigilante Big Brother. A legislação desce dos céus; não nasce da história. A lei é um mito da U topia, que cria e mantém a uniformidade social. A ssimilados ao Estado, os indivíduos são unânimes e a sociedade fica livre de conflitos. As classes são criadas. Platão queria três, Fenelon criou sete. Sob a vigilância e o dirigismo total, o cidadão é escravo, mesmo em Campanella e M orus, que trouxe a inovação dos "escravos públicos". C asas iguais, mudanças periódicas de domicílio, refeições comunitárias, casamentos planejados por razões de eugenia e tantas medidas que preparam um Estado que intervém ao máximo, como na antiutopia de H uxley.

f) Coletivismo absoluto: até mesmo a felicidade na $U$ topia é coletiva, pois o utopista tem horror ao segredo, que é uma recaída individual ista. 0 autor denarrativas utópicas sonha com a transparência absoluta. Daí as casas de vidro, os televisores e o olho onipresente do Big Brother. Como nos manicômios, prisões e conventos, estudados por Foucault e G offmann, o tempo e o espaço são absolutamente controlados: a instituição sabe de tudo que 0 indivíduo tem e tudo que ele faz, e ele deverá, aliás, estar sempre ocupado.

g) Pedagogia estatizada e hostil à natureza, pois a criança é naturalmente individualista e anárquica. 0 estado se encarrega de desenvolver nela uma outra natureza, adequada a sua função.

h) Total itária e humanista ao mesmo tempo, a U topia aspira à síntese e à harmonia e revela um inegável otimismo antropológico, poiscoloca o homem no centro do mundo, mestre de seu destino.

Estabelecidas essas características da U topia, é possível classificar os gêneros aparentados a ela: 0 tema da Idade de 0 uro, 
como em 0 s trabalhos e os dias, de Hesíodo, é a nostalgia de um passado perdido para sempre; o país da C ocanha é um paraíso de glutões e bêbados; a Arcádia renascentista ou barroca é um local refinado de fuga, onde o indivíduo é rei e são suspensas até as leis da física sob o condão das fadas; as viagens imaginárias como um fim em si - já que para se chegar ao "país de parte al guma" é sempre necessário alguma viagem - e, por fim, como já vimos, as robinsonadas, que tratam do choque cultural acompanhado da vontade de voltar à metrópole.

\section{Política, na ordem da razão e da experiência}

0 contrato social é uma concepção que projeta no passado a origem da sociedade, enquanto a narrativa utópica projeta no futuro a possibilidade de sua realização ideal. São duas construções com expressão de traços míticos e ambas enraizadas no presente, pois tanto o filósofo contratualista quanto o criador de relatos utópicos partem da análise da sociedade e do momento em que vivem. A esquematização de N orthrop Frye, que pretende com isso destacar o elemento da ritual ização, tal vez não se encaixe em nossa tipologia, ao remeter a U topia para o futuro, como predição, mas servenos para colocar a questão: se ambas as explicações são míticas e provocadas pelo presente, por que é então que o contrato social é tido habitual mente como parte integrante da teoria social, ao passo que a utopia é menosprezada como ficção? A U topia de M orus, que é contemporânea d'0 príncipe de Maquiavel, não foi lida como orientação pragmática e não tem o status de texto teórico, devido, inclusive, a seu caráter especulativo. M aquiavel cita guerras, traições e acordos que de fato ocorreram na história recente da Europa, ao passo que M orus fantasia sobre a vida em uma sociedade perfeita que, caso exista, está em outro lugar.

Comparem-se os gêneros ensaio e tratado, que são geralmente 0 veículo das doutrinas e teorias que mais interessam à filosofia. $0 \mathrm{~s}$ 
ensaios políticos de H ume, por exemplo, pertencem, segundo um editor, "ao campo dos conhecimentos que integram os usos, costumes e conven ções, mas se referem a temas técnicos ou eruditos que não têm nada a ver com a filosofia de Hume propriamente dita", presente nos tratados a respeito daquilo que é permanente, ou seja, a natureza humana. O ra, Koyré chamou a atenção para os "tratados do método", que, no século XVII, desempenharam o papel terapêutico de medicina mentis, como exercício e resultado do uso adequado da razão, livre dos "ídolos", das superstições e do argumento de autoridade. Assim, os escritos de Spinosa, Locke, H ume e mesmo o Discurso do método puderam aplicar-se com sucesso à ordem da razão eà ordem da experiência, para criar conhecimento sistemático e seguro. 0 mesmo Koyré que elogia tais provas de confiança na razão representa bem a tradição que desqualificou 0 ensaio como gênero filosófico; ao comemorar três séculos de cartesianismo, referiu-se aos ensaios de M ontaigne como o "tratado do desespero". Cremos, todavia, que nos últimos cinqüenta anos, inclusive graças aos desacertos da fil osofia sistemática, o en saio já se estabeleceu como legítimo recurso da filosofia, sobretudo para aquela que se entende como crítica.

O ra, se o tratado promete uma abordagem segura e talvez exaustiva, com base em método confiável, e 0 ensaio fica relegado ao nível da opinião eventualmente diletante, 0 que dizer da narrativa utópica? Ao lado da ordem da razão e da ordem da experiência, a mentalidade cientificista dificilmenteadmitiria uma ordem do sonho ou da fantasia.

\section{Verdade na ficção: estratégias literárias}

As narrativas utópicas de M orus e C ampanella dedicam-se mais explicitamente a um modelo de organização social, mas também nelas a ciência tem um papel importante como instrumento do progresso e da educação. Por sua vez, um conto de A simov 
ou de Bradbury, ou mesmo os clássicos de H uxley e O rwell, tidos como textos de ficção científica, despertam reflexões sobre o ordenamento político que descrevem e o momento histórico vivido pelos autores. Sem querer a esta altura retomar a tarefa da definição de conceitos, para deixar mais claro o que seja o subtipo science fiction, admitamos que essa literatura popularizada e adaptada para o cinema e os gibis teve seu auge na esteira dos regimes totalitários e durante a G uerra Fria. N esse contexto, é compreensível quemuitas obras tenham desandado em antiutopias ou utopias negativas.

H oje vivemos numa situação de certo modo vantajosa, pois se chegamos ao futuro tão anunciado, ficamos livres de fazer profecias e previsões, sobretudo as catastróficas. Datas emblemáticas já chegaram e passaram, como 1984 (de O rwell), 1997 (do filme Exterminador do futuro), e 2001, ano da nova odisséia. 0 Big Brother da ficção tornou-se show de real idade, e certamente não chegaremos ao ano de 2020 sem comer as bolachas verdes do filme Soylent green, ou a 2072 sem poder elogiar os benefícios do tabaco, como fez Woody Allen em 0 dorminhoco. Todavia, jamais superaremos os medos e as carências que os replicantes de Blade Runner experimentaram, pois temos, como eles, complexo de rejeição diante do nosso criador - e desejo de matar o pai. Nosso estranhamento nos leva ao complexo de adoção, e gostaríamos de viver mais do que nos cabe viver. Por isso, B lade Runner é, também para a psicanálise, uma história fictícia e verdadeira.

A questão da verdade na literatura de ficção, inclusive na science fiction, não se reduz ao valor de verdade de enunciados com verbos no futuro. Paul Tillich arma um jogo de conceitos opostos para caracterizar a U topia, com suas inten ções de teólogo progressista. A utopia é verdade, fecundidade e poder, ao mesmo tempo em que parece como não-verdade, esterilidade e impotência. Ela é, primeiramente, verdade, "porque expressa a essência do homem, o fim próprio de sua existência. [...] Toda utopia não é senão uma manifestação do que o homem tem como fim próprio e o que deve ter para realizar-se como pessoa", e, por conseguinte, a rejeição, 
"seja cínica, seja filosoficamente, é uma negação dessa verdade". 20 É como se Tillich dissesse: "é verdade que temos o costume de escrever e ler narrativas utópicas com certo grau de convicção e engajamento". É assim que somos e assim fazemos, pois gostamos de sonhar, de imaginar um mundo diferente e, sobretudo, melhor que este.

A verdade da utopia é também de natureza contrafatual: vivemos no presente como se vivêssemos no futuro maravilhoso ou na barbárie, seja ela situada na pré-história ou no presente. Aliás, parafraseando Walter Benjamin, a convivência de alta tecnologia e mortos de fomeéa barbárie aqui eagora. 0 cenário de B lade Runner reúne a alta tecnologia de viaturas policiais flutuantes a ruas atulhadas de mercadorias, camelôs e mestiços, como na atual Chinatown. No filme, o anúncio de um refrigerante que conhecemos nos leva a pensar na continuidade do capitalismo industrial até o futuro ou nos alerta para os elementos de barbárie e desejo já presentes em nosso momento atual.

M orus queria saber de R afael, o narrador-guia, como é a ilha utópica e onde ela está. G eralmente, não se pergunta se é verdade o que diz o viajante ou se tal lugar existe mesmo. Na estratégia literária da utopia, o ouvinte - e, depois, o leitor - confia no narrador: a expectativa de validade que mais interessa é a veracidade e não tanto a verdade. A reação do ouvinte M orus é antes a de pedir mais detalhes, mais informações. $\mathrm{N}$ ão cabe perguntar se cada coisa e cada instituição de nenhures existe mesmo ou se cada sentença pronunciada está em harmonia com os fatos. M orus, aliás, transfere o ônus da prova ao marinheiro Rafael, testemunha, narrador e personagem da narrativa.

A verdade da ficção obedece também a imperativos literários, pois mesmo em mundos imaginários não se podem confundir as ações e as falas dos personagens; mesmo os mutantes devem ser reconhecidos na seqüência da trama. $E$, por mais que se viaje no tempo cronológico, a velocidades espantosas, o tempo da narrativa deverá respeitar alguma ordem compreensível. A ficção deve ser, 
sobretudo, verossímil, mesmo que a obra não seja conclusiva. N ão cabe perguntar qual é a verdade em Dom Casmurro. Capitu pode ter traído ou não. Não se pergunta se o protagonista do romance de James Joyce existiu mesmo, mas a cada ano comemora-se 0 "Bloomsday" pelo mundo afora.

A cobrança da verdade, na versão realista, talvez pudesse contentar-se com a solução de al guma semântica construtivista: Sacis existem em fábulas de Saci e são diferentes de Caiporas, de modo que, se você visse um ou outro, poderia reconhecêlos. Assim seria, também, se você chegasse a uma certa ilha em forma de croissant. Todavia, há uma diferença fundamental: a história de Saci não supõe o leitor, mas o autor da narrativa utópica, através do truque do narrador-guia, leva o leitor e o próprio autor a desejarem viver em uma ilha ou, pelo menos, visitá-la para poder depois imitá-la.

A verossimilhança, bem tematizada na fórmula "jardins imaginários com sapos autênticos", implica respeitar não tanto as descobertas científicas, mas antes as convenções literárias. C reio que as reflexões sobre a verdade nas narrativas de science fiction valem também, até certo ponto, para as narrativas utópicas em geral. Não basta admitir a resposta tão genérica de que o adjetivo "científica" garante à ficção o status de discurso racional, ou seja, não-contraditório, não-emocional, não-instintivo. M esmo que 0 critério de verdade da science fiction fosse o critério de verdade da ciência, teríamos de admitir que uma versão popperiana facilitaria as coisas para a literatura, pois "enquanto épossível provar a falsidade de uma premissa, não é possível provar sua verdade. N ão é o caso de que na science fiction o uso da ciência confere aos textos um peculiar e privilegiado acesso à verdade". ${ }^{21}$ Embora alguns autores revisem seus textos para que as novas edições fiquem de acordo com os avanços da ciência e satisfaçam os leitores, o fato de que as pesquisas recentes ten ham negado a existência de canais e oceanos em Marte não invalida as narrativas mais antigas, "porque o que interessa na science fiction não é a 'verdade' mas o ingresso em um 
discurso particular, material e freqüentemente racional" ${ }^{22} \mathrm{C}$ remos que isso valeria para os textos utópicos em geral.

A síntese das utopias é inviável, pois os autores de narrativas e modelos utópicos, além de certa predileção pela topografia das ilhas, tendem eles mesmos ao isolamento; o máximo que se consegue da comparação de tais textos é hoje a esperança de que o mundo será diferente no futuro. $N$ aturalmente, os relatos quase sempre fabulosos de viajantes sempre animaram a imaginação da metrópole, sobretudo no século XVI, quando se acreditava ainda que haveria lugares no mundo onde a vida, inclusive política, era de fato não apenas diferente, como também melhor que a da velha Europa. Mesmo o mito do antípoda deve admitir uma base antropomórfica: ele dorme enquanto eu fico acordado, come coisas diferentes, fala outra língua, está de cabeça para baixo, mas é ainda um ser humano.

Assim, o balanceamento de "cognição" e "estranhamento" é 0 índice que garante 0 sucesso dos textos de science fiction. 0 equilíbrio entre continuidades e descontinuidades é focalizado através do novum, que "atua como manifestação simbólica de algo que o conecta especificamente com o mundo em que vivemos". ${ }^{23}$

\section{U topia como crítica}

U topia é verdade a ser interpretada, através de uma narrativa simbólica. A realidade pode estar espelhada ou invertida, com referência também a uma época ea uma específica formação social. E nem sempre as narrativas são sátiras da anarquia; elas podem querer justamente a implementação da anarquia e da preguiça, como em Pasárgada. Todavia, não se pode supervalorizar certo perspectivismo, pois, embora seja verdade que os descobrimentos de novos continentes e povos no século XVI incitaram a imaginação dos europeus, sobretudo a de M orus, que escreveu a obra-mãe das utopias, também éverdade que povos primitivos, como os guaranis, 
já buscavam a "terra sem males" antes do contato com o branco. Segundo Eliade, essa utopia primitiva não énem uma simples reação à desestruturação trazida pela aculturação e nem o resultado da influência dos mitos cristãos. ${ }^{24}$

A lém, portanto, de uma perspectiva mais ampla da antropologia quanto a valores e carências universais que possam guiar a crítica, devemos reconhecer e propagar um pouco mais as conseqüências da conquista da A mérica para a crítica do eurocentrismo: A mérico Vespúcio sugeriu em suas cartas que o paraíso terrestre narrado pela Bíblia ter-seia situado no Brasil. Thomas M orus tomou conhecimento das cartas e teria encontrado na Bélgica o português R afael Hitlodeu, companheiro de viagem de Vespúcio, que narra 0 diálogo da U topia. O s habitantes do N ovo M undo teriam dado aos europeus exemplos de organização social e de convivência, que serviriam para "corrigir erros cometidos em nossas cidades e países", afirma Rafael. ${ }^{25}$

M orus tinha consciência de estar redigindo al go diferente da literatura de viagens e de relatos fabulosos, certamente ao gosto dos marinheiros, que temiam os mares povoados de monstros. 0 autor deve resumir o que ouviu do viajante Rafael, para concentrarse nas

sábias instituições que ele observou nos povos que vivem em sociedades civilizadas. Foi sobre essas questões que 0 interrogamos mais avidamente e que ele nos respondia com mais prazer, não perdendo tempo em descrever-nos monstros, que são tudo que há de mais antiquado. Cilas, Celenas e $\mathrm{H}$ arpias vorazes, lestrigões canibais e outros prodígios medonhos do gênero, em que lugar que não se encontram? $M$ as homens vivendo em cidades sabiamente governadas, eis 0 que não se encontra em qualquer lugar. ${ }^{26}$

Mais interessante que os monstros, a narrativa de Morus é que é uma novidade, mas a ilha $U$ topia é muito antiga, certamente mais antiga que a civilização européia. U topia teve contato com os 
romanos e os egípcios, e ali se utiliza uma língua muito semelhante ao persa, que conserva nomes gregos para os toponímicos; enfim, diz Morus, "creio adivinhar que sejam gregos de origem". Se os utopianos não são autóctones, isso equivale a não serem bárbaros, o que implica mais um artifício da crítica de M orus, pois, enquanto os utopianos aprenderam o que havia de melhor naqueles povos, a Europa que dali de fato descende só fez degenerar-se.

Pode-se ler a U topia com a intenção de procurar contradições internas - e, talvez, nem queiramos mais morar lá -, mas seria mais fácil ain da en saiar uma crítica sobre como a narrativa fantasiosa de M orus não chega a tocar no espírito colonialista que então ia-se instalando, à sombra da expansão da cristandade. H á colônias, fora da ilha, para controlar sua população estável; há escravos, para as tarefas mais insalubres e degradantes, como as dos matadouros de animais; há "escravos públicos", que conduzem de carroça os viajantes; a sociedade deU topia é, aos olhos de hoje, extremamente opressiva e castradora: os mais velhos são os chefes, cultivam-se jogos de guerra, os homens mandam nas mulheres, velhos vigiam adolescentes à mesa, "nada de cabarés, de tavernas, de casas de jogos, nenhuma ocasião de libertinagem, nenhum antro, nenhum local de encontros amorosos". N ão se permite sexo antes do casamento - embora o noivo possa examinar a noiva nua, "seja virgem ou viúva", como quem examina um cavalo sem a sela... E parece ainda que lá estava um protótipo do Panóptico de Bentham: "Sempre exposto aos olhos de todos, cada um é obrigado a praticar seu ofício ou a entregar-se a um lazer irreprochável."27

Algumas extravagâncias aparecem na obra de Morus, mas talvez sejam mais próprias do expediente que ele utilizou, colocan do $R$ afael a narrar o que teria visto, ou seja, cabe bem ao gênero ligado a uma literatura de viagens floreá-la com curiosidades - mas não monstruosidades - , pois o que se quer é mostrar as instituições da ilha. Por exemplo, os utopianos fazem de ouro seus penicos e as correntes dos escravos para que as crianças possam crescer desprezando a vaidade de possuir tal metal. 
O sutopianosnão são os antípodas dos conterrâneos de M orus; por isso o texto está corretamente articulado. Salvo algumas inversões, como a do penico de ouro, as diferenças são eventualmente de grau ou são aplicações racionais de princípios que os europeus também deveriam reconhecer, como a tolerância religiosa e 0 direito à eutanásia. Todavia, o que mais interessa na narrativa e que certamente faz dessa obra ficcional uma fonte de interesse também para a filosofia política é seu pragmatismo diplomático talvez bem próximo do contemporâneo M aquiavel -, que consiste, por exemplo, em utilizar o excedente da produção para comprar a traição, promover a guerra civil entre os inimigos e contratar mercenários, sobretudo os da Suíça, que fica a quinhentas milhas da ilha U topia. "Esses homens fazem guerra contra todo o mundo porque ninguém os paga melhor." 28

Tomás M orus, recentemente canonizado pela I greja C atólica, teria sido também homenageado pela Rússia bolchevique. $\mathrm{Na}$ verdade, algumas medidas tomadas na ilha $\mathrm{U}$ topia lembram mais a China de $\mathrm{M}$ ao, com aquela singeleza de vestimenta uniformizada, doutrinação constante e, sobretudo, com o fim da propriedade privada. Algumas outras idéias, por racionais que são, como as cozinhas comunitárias, seriam defendidas durante a Revolução Industrial pelo próprio H enry Ford; a tecnologia liberaria sobretudo a mulher, para que também ela pudesse ir para a fábrica.

A U topia é uma crítica da sociedade européia, que passava por uma terrível crise no início do século XVI. Também a escolástica se viu ali criticada; M orus ridiculariza não só o sábio inútil, como também a escolástica que o educava através dos "Pequenos Tratados de Lógica". Também por desprezar os recursos da dialética, das artes das disputas, é que Morus prefere o gênero do texto fantástico, narrado por um testemunho idôneo; assim, coloca-se a proposta pela via indireta da narração, mas sem se submeter às armadilhas da polêmica viciada por estratégias meramente formais e retóricas.

Morus utilizou uma estratégia para primeiro expor um panorama não só de problemas dos países europeus por onde 
circulava, como também das discussões inconclusivas que a respeito se travavam. Como uma comédia em dois atos, Morus conversa com seus amigos, o editor Pedro Gilles e o viajante português R afael, quando se referem a uma discussão que envolve um cardeal, um jurista em "muito aferrado ao direito inglês" e um parasita. Em torno de questões como a melhor forma de governo e o que fazer com os ladrões e pobres, vemos um desfile de preconceitos e despotismo, ao mesmo tempo em que se revelam as estratégias da discussão: "enquanto eu falava assim, o jurisconsulto havia preparado sua réplica, com a intenção de seguir o famoso costume dos debatedores que são mais hábeis em repisar do que em responder, pois seu ponto forte é a memória". ${ }^{29} 0$ cardeal, por sua vez, se apropria dos argumentos do próprio Rafael, de modo que aquilo que antes provocou o desprezo dos outros, agora era louvado, devido, naturalmente à subserviência diante do cardeal, que também despacha o parasita e muda a conversa quando Ihe convém. O ra, no primeiro ato vemos uma demonstração de como as discussões não obtêm efeito, o que justifica a maneira direta como a narrativa se apresenta.

U ma obra deficção - que, contudo, apela para al guns recursos que a tornem verossímil - não requer o debate; a única falha da qual se ressente o narrador é saber a local ização exata da ilha U topia. A s instituições que a compõem não se submetem a nossa opinião; elas estão instaladas e funcionando harmonicamente de modo que nem mesmo lá os utopianos queiram discutir sobre sua possibilidade, pois ali já são reais. N ão podermos localizar a ilha talvez seja também uma estratégia al tamente responsável de M orus e por isso também crítica de nossa tendência escapista, pois, por mais que possa explorar o lado romântico e piegas que geralmente se associa ao tipo utopia, na verdade, M orus arremata o relato de Rafael, avaliando: "há na república utopiana muitas coisas que eu desejaria ver em nossas cidades". ${ }^{30}$ A ssim, o lugar nenhum poderá ser aqui; as instituições justas poderão ser as nossas ou outras que adotemos. 
0 texto de M orus impressiona e sobrevive, também, ao trazer contribuições em torno de problemas como a pena de morte e de conceitos como o interesse público. Sobre a pena, entendia M orus - ainda no preâmbulo que antecede a narrativa fantasiosa - que "esse castigo vai além do direito sem na verdade servir ao interesse público. Eleéao mesmo tempo demasiado cruel para punir o roubo e impotente para impedi-lo". ${ }^{31}$ M orus aparece ao final do texto por detrás do relato do amigo, com a consciência de que seu projeto de sociedade tinha se utilizado do meio correto de expressão: "descrevi a vocês o mais exatamente possível a estrutura dessa república que considero não somentea melhor, mas aúnica que mereceessenome. Todas as outras falam do interesse público e cuidam apenas dos interesses privados". 32

\section{Crítica da U topia}

Tenho procurado duas coisas em minha pesquisa sobre os gêneros literários da filosofia: localizar declarações do próprio autor sobreo gênero que utiliza emeditar sobre uma questão fundamental em cada caso. M orus escreve e sabe como escreve; opta por um gênero - aliás, inventa-o - e o justifica.

Sei, contudo, que nem sempre conseguirei encontrar tal questão fundamental. Por exemplo, a biografia e mais ainda a autobiografia caracterizam-se pelo impulso ético de uma vida que se quer lida, que se quer levar digna de ser descrita. 0 ensaio é pautado pela interrupção, pela retomada constante e pela digressão, devido a uma experiência da finitude: a certeza da morte que virá nos surpreender no meio de uma obra inacabada. 0 que posso dizer do texto utópico? 0 que é que o caracteriza? É a pressa que 0 caracteriza e determina. 0 narrador tem pressa de contar, pois tem pressa de voltar para sua ilha. U m navio o espera. 0 modelo político queo sustenta tem pressa de se implantar, geralmente por imposição de um ditador bem-intencionado. 0 autor de utopias vê seu 
momento como anarquia e quer uma solução rápida, racional, centralizadora. Assim, a revolução é herdeira da utopia, mesmo em sua versão marxista, ou seja, científica, porque se acha a parteira da história. A vanguarda, assim como o viajante que descreve a ilha, considera-se possuidora de uma clarividência para determinar quando a história está madura para a revolução. Morus, de fato, associa a pressa aos interesses dos oprimidos, não tanto para desestimular a revolução, mas antes para criticar o controle social através da submissão dos pobres.

Q uanto a crer que a miséria do povo seja uma garantia de segurança e de paz, a experiência prova suficientemente que esse é o maior dos erros. O nde há mais desordem do que entre os mendigos? Q uem é o mais apressado em subverter 0 estado de coisas existente senão o que está descontente com sua sorte? ${ }^{33}$

A pressa identifica-se também no recurso literário da concisão que traz elegância ao texto, pois a brevidade é uma virtude da boa conversa, anterior à literatura. O cavalheiro Rafael gostaria de resumir seu relato, inclusive para voltar logo à ilha afortunada. M orus hesita em publicar seu livro e já demarca o perfil da crítica que ele gostaria de não receber.

M orus considera os monstros antiquados e prefere ouvir de R afael os detalhes de funcionamento da I lha U topia. 0 socialismo científico, por sua vez, condenará o pensamento utópico como atrasado e retrógrado. Seja como for, não escapamos ainda das monstruosidades e nem esgotamos ainda as energias utópicas. Antes da elaboração literária renascentista, os monstros do imaginário popular medieval ${ }^{34}$ também tinham uma função crítica, pois as superstições a respeito das monstruosidades geradas por relações sexuais impróprias e bizarras apontavam de maneira muito confusa para a causa e a responsabilidade; "monstros" e "mostrar" têm raízes comuns. As aberrações produzidas pelo homem são um signo, uma mensagem, um alerta. D istante do mau gosto das monstruosidades, 
M orus prefere a beleza da narrativa da bela novidade, que se quer também verdadeira. Seu texto inaugura um gênero e se declara pela verdade: "se quero fazer prevalecer a verdade, não posso dizer o contrário dela. Será a tarefa de um filósofo dizer mentiras? N ão sei, mas em todo caso, não é a minha?"

ABST RACT: Philosophical texts are usually classified under the literary genders of treatises and essays, but political theory is also indirectly influenced by utopian writings and utopian experiments. The validation of a treatise depends on the method it follows and for an essay the author's reliability is what counts, but it is not clear how to decide the truth value of an utopian narrative that ranges from nostalgia to dream. The past events concerning islands and paradises can be checked by chronology, but it is quite dificult to evaluate counterfactual and future tense statements. As far as literature knows how to deal with fiction, philosophy tries to preserve the critique for nowadays polis.

Key words: fiction, truth, philosophy.

\section{N otas}

1. H orkheimer (1980, p. 138-139). Ao termo "utopia", Alfred Schmidt acrescentaria o restritivo "abstrata", o que salvaria um sentido para a utopia na teoria crítica como utopia concreta ou determinada, da mesma forma que seria possível, segundo R. G euss, por exemplo, falarmos de uma ideologia em sentido positivo ou programático.

2. Ibidem, p. 139.

3. Buber (1971, p. 15).

4. Idem.

5. Habermas ([1984], p. 7ss).

6. Wellek e Warren ([1962], p. 267ss).

7. Ibidem.

8. A obra de Trousson, Voyage aux pays de nulle part, contém farta revi são da literatura, apontando equívocos em coletâneas, como a de G. Dubois, que confunde espírito utópico e utopia, reunindo M orus, Campanella, Bacon, Cervantes e outros; Ph. B. Gove tenta separar viagem imaginária e utopia, misturando robinsonadas com utopias.

9. Trousson, op. cit., p. 20. 
10. Ver, por exemplo, em Luis G. Tovar et al. U topias libertárias americanas, os projetos arquitetônicos de Pierre Q uiroule, por volta de 1914, para destruir Buenos Aires e erguer uma cidade racionalmente planejada em Santa Fé, onde, todavia, os gaúchos não teriam privilégios.

11. Cf. Hardy (2000).

12. A obra de Euclides da Cunha é muito importante para a formação de outro gênero literário relevante no Brasil.

13. Trousson, op. cit., p. 25.

14. Trousson, op. cit., p. 22-24.

15. Wellek e Warren (apud Trousson, op. cit., p. 25). Cf. também 0 significado germinal que teve a obra de Defoe para caracterizar 0 gênero das robinsonadas, que se distingue das narrativas utópicas genuínas, sobretudo porque o náufrago quer voltar para a metrópole.

16. H á também textos dramáticos. Trousson refere-se a M arivaux, C apek e Bernard Shaw, na página 9, nota 10.

17. Trousson, op. cit., p. 19 e segs.

18. Cf. Trousson, op. cit.

19. N a U topia de Morus, desde cedo as crianças se acostumam a desprezar tais metais, pois os urinóis são feitos de ouro, assim como as correntes que prendem os escravos.

20. Tillich (1982, p. 351ss).

21. Roberts (2000, p. 9).

22. Ibidem, p. 9.

23. Samuel D elany e Suvin, citados por Adam Roberts (2000), vêem a science fiction como um gênero simbolista - que representa o mundo em vez de reproduzi-lo -, com uma riqueza de interpretações, diferentemente da alegoria, que mapeia o significado.

24. Eliade (1982, p. 323ss). Todavia, ainda por volta de 1910, os guaranis admitiam que não conseguiam levitar rumo ao paraíso da "terra sem males", por culpa das roupas de branco que trajavam.

25. Cf. Rohden (2001). 
26. M orus (1985, p. 21).

27. Ibidem, p. 94.

28. M orus (1985, p. 139).

29. Ibidem, p. 35.

30. Ibidem, p. 166-167.

31. Ibidem, p. 27.

32. Ibidem, p. 61.

33. M orus (1985, p. 54).

34. Cf. Lexikon des Mittelalters, v. 6 , verbee M onster.

\section{Referências}

Buber, Martin. 0 socialismo utópico. Tradução de G. G. de Souza. São Paulo: Perspectiva, 1971.

Campanella, Tommaso. A cidade do sol. Tradução de Aristides Lôbo. 2.ed. São Paulo: A bril Cultural, 1978. (O s Pensadores).

EliAde, Mircea. Paraiso y utopía: geografia mítica y escatologia. In: M anuel, Frank E. U topías y pensamiento utópico. Tradução de Magda Mora. Madri: Espasa-Calpe, 1982. p. 312-333.

Fourier, Charles. 0 novo mundo industrial esocietário e outros textos: analogia. Tradução de Patrícia Boanova. Porto, 1973.

Frye, N orthrop. Diversidad de utopías literárias. In: M anuel, Frank E. U topías y pensamiento utópico. Tradução de Magda M ora. M adri: EspasaCalpe, 1982. p. 55-81.

H ABERMAS, Jürgen. Sobre la perdida de confianza en si misma de la cultura occidental. Revista de las C ortes $G$ enerales, [1984].

HARDY, Dennis. U topian England: community experiments 1900-1945. Londres: E \& FN, New York: Spon: Routledge, 2000.

H orkheimer, M ax. Teoria tradicional eteoria crítica. In: Benjamin, Walter et al. Textos escolhidos. Tradução de E. A. M alagodi e R. P. Cunha. 2.ed. São Paulo: A bril Cultural, 1980. p. 117-154. (O s Pensadores).

LexIKon des Mittelalters. Stuttgart: Metzler, 1999. 
Manuel, Frank E. Introdução. In: Manuel, Frank E. (O rg.). U topías y pensamiento utópico. Tradução de Magda Mora. Madri: Espasa-C alpe, 1982. p. 9-27.

M orus, Tomás. A utopia. Tradução de José M arinho. Lisboa: Guimarães Editores, 1985.

Roberts, Adam. Science fiction. Londres, New York: Routledge, 2000.

RoHDEn, Valério. U topia como idéia crítica. Theophilos. Canoas: U Ibra, v. 1, n. 1, p. 205-219, jan./ jun. 2001.

TIllich, Paul. Crítica y justificación de la utopia. In: Manuel, Frank E. U topías y pensamiento utópico. Tradução de Magda M ora. M adri: EspasaCalpe, 1982. p. 351-365.

Tovar, Luis Gomez et al. U topías libertárias americanas: la ciudad anarquista americana de Pierre Q uiroule. [s.l.]: Ediciones Tuero/ Fundación Salvador Seguí, [s.d.].

Trousson, Raymond. Voyage aux pays de nulle part: histoire littéraire de la pensée utopique. 2.ed. Bruxelas: Ed. Univ. Bruxelas, 1979.

Wellek, René; W arren, Austin. Teoria da literatura. Tradução de José Palla e Carmo. Lisboa: Publicações Europa-A mérica, [1962]. 